\title{
Composition and microbiological analysis for quality evaluation of Kars Gravyer cheese: influence of ripening period
}

\author{
Asya ÇETINKAYA ${ }^{1 *}$ (D), Fatih ÖZ ${ }^{2}$
}

\begin{abstract}
In this study; The objective is to demonstrate the total quality of the chemical and microbiological aspects of the Kars Gravyer cheese during the ripening period, produced by means of traditional method in dairy conditions. Production of Kars Gravyer cheese was performed in two replications. Titratable acidity (\%l.a), salt content, total protein ratio, dry matter, fat content, dry matter in fat and dry matter in salt, total nitrogen and lipolysis rate content were determined by taking samples from the produced cheeses on specific days (day 0, 10, 25, 45, 60 and 90) and microbiological analyses were performed. By analysis the results of the Kars Gravyer cheese samples; significant changes in acidity, dry matter, salt, total nitrogen, protein, fat and dry matter in fat, dry matter in salt, lipolysis (ADV) values of cheese produced 90 days of maturation period were found significant $(P<0.001)$. The number of lactobacilli microorganisms and psychrophile microorganisms wasn't significant $(P>0.05)$. It was determined that the difference between total aerobic mesophilic microorganisms, lactococci bacteria and yeast counts of cheese was significant $(P<0.001)$. Values obtained at the end of maturation stage was found to be between determined range in accordiance with TS 2174 Gravyer Standard.
\end{abstract}

Keywords: Gravyer cheese; maturation; quality; food analysis; food composition.

Practical Application: Values obtained from this study will contribute to the production-based work and analysis for quality evaluation related to Kars Gravyer cheese.

\section{Introduction}

It is estimated that there are 4000 different type of cheese in terms of aroma and texture and Gravyer cheese an important one of those different types (Steele \& Ünlü, 1992). In Turkey, in addition to a large variety of cheese produced using traditional methods, several types of European cheese such as Emmental and Gravyer cheeses are also produced. It is indicated that there are around 193 types of cheese in Turkey (Cetinkaya, 2005). Milk production in Turkey is 18.489 .161 tons according to data obtained in 2016. Cheese production is 1.209 .057 tons and $25.62 \%$ (309.822 tons) of the production is white cheese, $14.64 \%$ (177.120 tons) kashar cheese, $1.41 \%$ (17.149 tons) Tulum cheese and $58.27 \%$ other types of cheese (Tuik, 2016). A couple of European type cheeses like Gravyer are also produced in Turkey. 90\% of Gravyer cheese production (544 tonnes) which is mainly in the East Anatolia Region is carried out in Kars (Kars Sanayi ve Ticaret Odası Müdürlügü, 2015). The number of establishments producing Gravyer cheese around Kars is limited. Instead, production is done in dairy farms with the help of traditional techniques (Düzey II Bölgeleri Kalkınma Program1, 2007). It is also valuable for the people living in the region. Kars Gravyer cheese has brand awareness in nationwide (Ulutaş et al., 1993).

The shell of Kars Gravyer cheese which is produced with traditional techniques is rigid and light smudgy looking brown color. The avarage weight ranges from $20 \mathrm{~kg}$ to $70 \mathrm{~kg}$. The diameter of cheese wheels is between $40-65 \mathrm{~cm}$ and the diameter of pores is around $0.3-2 \mathrm{~cm}$. The maturation period changes between 3-6 depending on the size of the cheese (Turkish Standards Institution, 1989; Ulutaş, et al., 1993). Form of Gravyer cheese is similar to Gruyere and its taste is similar to Emmental (Adam, 1956; Yöney, 1970; Uçüncü, 2004). Maturation of cheese includes a series of complex chemical and biochemical reactions which gives its own taste, aroma, and structure. (Fox, 1989; Fox et al., 1996). Maturation period consists of three different biochemical reactions such as lipolysis, proteolysis, and glycolysis (Fermentation of lactose and its components glucose and galactose (Fox \& McSweeney, 1996). The biochemical reactions that occur in cheese during maturation are not in separate stages but often occur simultaneously and cause the cheese to acquire its own specific qualities (Cakmakc1, 2008).

There are few studies on Kars Gravyer cheese in Turkey. The researches done generally aim to determine the chemical and microbiological properties of Kars Gravyer cheeses sold on the market (Ulutaş et al., 1993; Kamber et al., 2008; Topuk \& Sezer, 2015). Any research on the production and maturation stages on the chemical and microbiological properties of cheese have not been found in the literature 
The objective of this study is to elucidate the changes occurrings in the maturation stage of the Kars Gravyer cheese.

\section{Material and methods}

\subsection{Material}

Gravyer cheese is produced in dairy farm located in the city of Kars, Boğatepe village according to flowchart in Figure 1. Production of cheese were done in two replications. Samples were taken at different maturation days (day 0, 10, 25, 45, 60 and 90) from the produced cheeses and brought to the laboratories under cold chain and analyzed immediately.

\subsection{Method}

\section{Microbiological analyses}

Total mesophilic aerobic bacteria, yeast, mould, coliform, psychrophile, lactobacilli and lactococci bacteria were determined in order to specify the microbiological characteristics of traditionally produced the Kars Gravyer cheese samples . Plate Count Agar (PCA, Oxoid) for total mesophilic aerobic bacteria and psychrotroph, PDA (Potato Dextrose Agar) for yeast and mould, VRB Agar (Violet Red Bile Agar) (VRB, Oxoid) for total coliform bacteria, Man Rogosa Sharpe Agar for Lactobacillus (MRS, Oxoid), M17 Agar for Lactococcus (Merck) were used. Incubation conditions were applied as follow: PCA for 48 hours at $30^{\circ} \mathrm{C}$ and 10 days at $6.5^{\circ} \mathrm{C}, \mathrm{PDA}$ at $25^{\circ} \mathrm{C}$ for 5 days, VRB at $37^{\circ} \mathrm{C}$ for $24-48$ hours, MRS in anaerobic media at $37^{\circ} \mathrm{C}$ for 72 hours and $\mathrm{M} 17$ aerobically at $37^{\circ} \mathrm{C} \pm 1{ }^{\circ} \mathrm{C}$ for 48 days (Halkman, 2005; Hagen \& Nervus, 1999; Turkish Standards Institution, 2004, 1996).

\section{Chemical analyzes}

The amount of dry matter in the cheese samples was determined with a gravimetric method (International Dairy Federation, 1982). Titratable acidity was determined with the

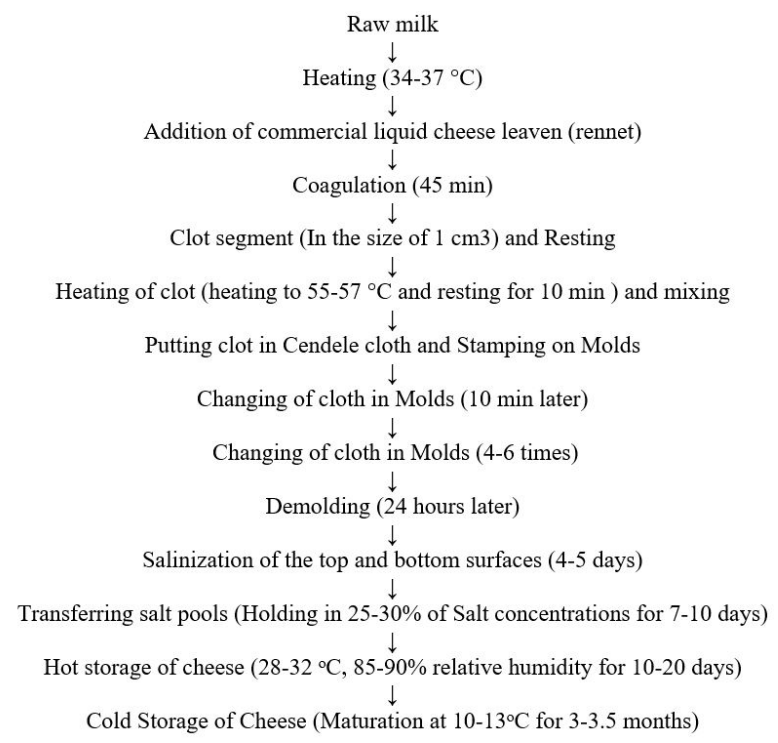

Figure 1. Production flowchart of Gravyer cheese. alkali titration method and results were specified in percentages of lactic acid \% (Turkish Standards Institution, 2006). The fat assay in the cheese samples was determined with the help of Gerber Method (Turkish Standards Institution, 1978). The amount of fat in dry matter was found by calculation. It was determined using the micro-Kjeldahl method accordance with International Dairy Federation (1993) and the total amount of nitrogen by Kjeldahl method was calculated by multiplying the factor of 6.38 and expressed as in percentages \%. The salt ratios of the sample prepared according to the Mohr titration method were determined by the titration with the adjusted $0.1 \mathrm{~N} \mathrm{AgNO}_{3}$ and the results expressed in percentagez \% (Turkish Standards Institution, 2006; Turkish Standards Institution, 1989). The salt amounts in dry matter were found by calculation The Lipolysis determination in Kars Gravyer cheese samples were determinated in accordance with the BDI method described in International Dairy Federation, 1991 and lipolysis levels were specified in Acid Degree Value (ADV) (International Dairy Federation, 1991).

\section{Statistical analysis}

The correlations between descriptive statistics and data obtained in the study were calculated using the SPSS program (Version 18) .

\section{Results and discussion}

The chemical and microbiological analysis values of the Kars Gravyer cheese samples were shown in Table 1 and Table 2.

\subsection{Chemical properties}

The changes in acidity, dry matter, salt, total nitrogen, protein, fat and fat in dry matter, salt in dry matter and lipolysis (ADV) values of the Kars Gravyer cheese samples are given in Table 1. The changes in acidity, dry matter, salt, total nitrogen, protein, fat and fat in dry matter, salt in dry matter and lipolysis (ADV) values of cheese produced during the 90 days maturation period are found to be significant $(P<0.001)$. The surface salting of Kars Gravyer cheeses which performed during salt curation and afterward in the production stage resulted in the easy separation of whey and the increase in the dry matter levels. In addition, the change in the dry matter can be affected by the composition of raw milk and cheese production conditions.

There is little research on Kars Gravyer cheese in Turkey. The studies are generally based on the determination of the chemical and microbiological properties of Kars Gravyer cheeses sold on the market, and no studies have been found that examine the effects of production and maturation stages on the chemical and microbiological properties of cheese.

In their study on 9 cheese samples of Kars Gravyer cheeeses sold in Kars Kamber et al. (2008) reported to find 32.4\% fat, $31.3 \%$ protein, $11.0 \%$ salt, and $1.54 \%$ l.a. acidity on average. According to the results of this study, the fat, protein and acidity ratio levels were similar. However, the salt ratio was found to be lower than the determined value of this study.

In a study investigating the chemical properties of Kars Gravyer cheese, it was determined that $68.20 \%$ dry matter, $33.45 \%$ 
Table 1. Changes in chemical compositions (\%) during ripening of Kars Gravyer cheese.

\begin{tabular}{|c|c|c|c|c|c|c|c|c|c|c|}
\hline \multirow{2}{*}{ Parameters (\%) } & \multirow{2}{*}{$\mathrm{n}$} & \multicolumn{9}{|c|}{ Ripening period (Day) } \\
\hline & & 0. Day & 10. Day & 25. Day & 45. Day & 60. Day & 90. Day & $($ mean \pm SD $)$ & F Value & $P^{\star}$ \\
\hline Acidity (\% l.a) & 2 & $1.06 \pm 0.03 \mathrm{a}$ & $1.45 \pm 0.02 \mathrm{bc}$ & $1.46 \pm 0.03 \mathrm{bc}$ & $1.47 \pm 0.03 c$ & $1.51 \pm 0.01 \mathrm{bc}$ & $1.56 \pm 0.21 \mathrm{~b}$ & $1.12 \pm 0.46$ & 87.41 & - \\
\hline Fat & 2 & $26.0 \pm 0.00 \mathrm{a}$ & $28.0 \pm 0.51 b$ & $29.5 \pm 0.70 c$ & $32 \pm 0.71 \mathrm{~d}$ & $33.57 \pm 0.72 \mathrm{e}$ & $35.5 \pm 0.71 \mathrm{f}$ & $26.67 \pm 9.70$ & 789.97 & - \\
\hline Total nitrogen & 2 & $4.81 \pm 0.06 \mathrm{a}$ & $5.22 \pm 0.06 b$ & $5.69 \pm 0.10 \mathrm{~d}$ & $5.70 \pm 0.04 \mathrm{~d}$ & $5.75 \pm 0.06 \mathrm{~d}$ & $5.43 \pm 0.05 c$ & $4.64 \pm 1.66$ & 8460.15 & - \\
\hline Protein & 2 & $25.53 \pm 0.43 \mathrm{a}$ & $30.90 \pm 0.21 b$ & $33.38 \pm 0.07 \mathrm{~d}$ & $36.31 \pm 0.09 \mathrm{~d}$ & $36.57 \pm 0.45 \mathrm{~d}$ & $34.85 \pm 0.27 c$ & $29.65 \pm 10.64$ & 7915.02 & - \\
\hline Lipolysis (ADV) & 2 & $0.78 \pm 0.03 \mathrm{a}$ & $1.80 \pm 0.01 \mathrm{~b}$ & $1.99 \pm 0.06 c$ & $2.33 \pm 0.11 \mathrm{~d}$ & $2.78 \pm 0.09 \mathrm{e}$ & $2.98 \pm 0.03 \mathrm{f}$ & $1.66 \pm 1.03$ & 624.35 & - \\
\hline Fat in DM (\%) & 2 & $43.95 \pm 0.06 \mathrm{a}$ & $44.31 \pm 0.01 \mathrm{a}$ & $45.06 \pm 0.04 \mathrm{a}$ & $46.48 \pm 0.02 \mathrm{~b}$ & $47.85 \pm 0.11 \mathrm{c}$ & $47.85 \pm 0.11 \mathrm{c}$ & $43.46 \pm 6.46$ & 371.89 & - \\
\hline Salt in DM (\%) & 2 & $0.75 \pm 0.04 \mathrm{a}$ & $1.94 \pm 0.07 \mathrm{~b}$ & $2.10 \pm 0.11 b$ & $3.15 \pm 0.40 c$ & $4.01 \pm 0.41 \mathrm{~d}$ & $5.21 \pm 0.33 \mathrm{e}$ & $2.22 \pm 1.74$ & 111.45 & - \\
\hline
\end{tabular}

Results are expressed as the mean \pm standard deviation of means; $\mathrm{n}=2$ sets of data analysed in duplicate; ADV $=$ Acid Degree Value; ${ }^{*}$ Different letters in the same line refers to significant differences between the averages $(P<0.001)$.

Table 2. Counts ( $\log \mathrm{CFU} \mathrm{g}^{-1}$ ) of micro-organisms during ripening of Kars Gravyer cheese.

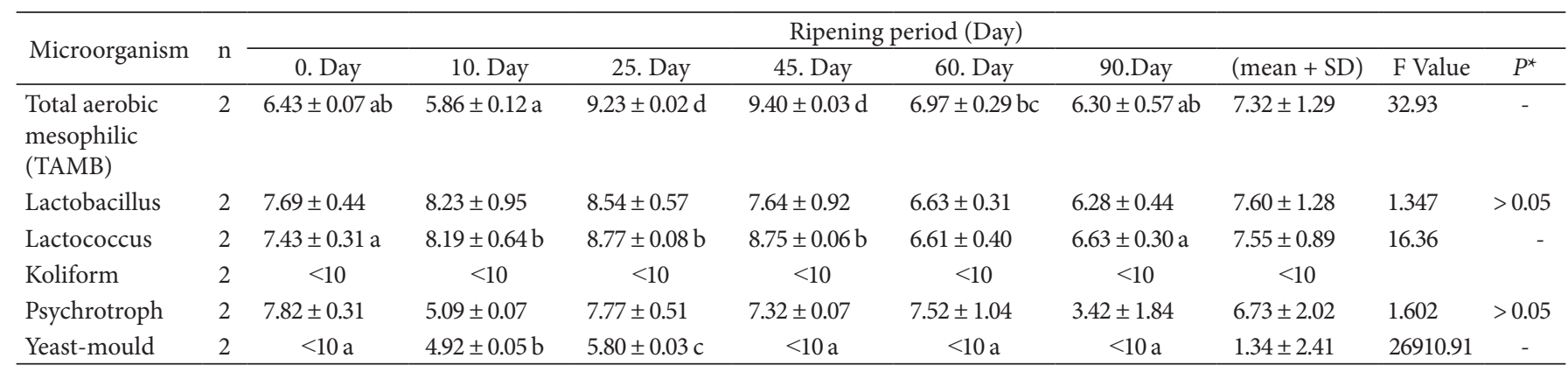

Results are expressed as the mean \pm standard deviation of means; $\mathrm{n}=2$ sets of data analysed in duplicate; ${ }^{*}$ Different letters in the same line refers to significant differences between the averages $(P<0.001)$.

fat, $35.01 \%, 28.95 \%$ protein, and 3.70\% salt were found in Kars Gravyer cheese (Ulutaş et al., 1993). In the study conducted on 40 Kars Gravyer cheese samples obtained from different sales points in Kars, it was stated that the fat content of the samples varied between $23-42 \%$, the dry matter ratio between $63.2 \%-79.63$, the protein amount between $23.7-33.3 \%$ and the salt content between 1.03-5.57\% (Topuk \& Sezer, 2015). The results obtained from the both studies are in parallel with the results. In the interviews with many cheese producers that produce cheese with traditional methods and the dairy farmer who produced the sample cheeses stated that the amount of salt was kept low for cheese maturation and pore formation

Grappin et al. (1993) has reported that the salt concentration is particularly effective in proteolysis in Gravyer cheese and in the formation of propionic acid fermentation. The effect of salt concentration on microbial flora, $\mathrm{CO}_{2}$ formation and pore formation in porous cheeses were investigated. In another study, it has been found that as the salt concentration increases, the amount and size of pores decrease (Huc et al., 2014).

Zerfiridis et al. (1984) has found that the $\mathrm{pH}$ and the amount of fat were quite high in the 6 months matured Gravyer cheeses. On the contrary, the salt ratio was considerably lower than the other Swiss cheeses.

Some researchers have found the titratable acidity (l.a \%), dry matter and salt values as $0.35-0.53 \%, 42.08-46.02 \%$ and
$3.87-5.33 \%$ in fresh and maturated Kelle cheese (Gölge, 2009) in the Kashar cheese produced without starter culture as $0.55-0.83 \%$, 54.93-58.04\% and 1.22-1.37\% Badem \& Uçar (2016) in Tulum cheese as $1.12 \%, 65.34 \%$ and $3.69 \%$ Dinkçi et al. (2012) and in Karın Kaymağ 1 cheese as $0.55-0.61 \%, \% 57.09-80.80$ and 2.32-3.33\% Karagöl (2017). The measured value of titratable acidity in Gravyer cheese was found to be higher than defined values by the researchers. The amount of dry matter is higher than defined values in Kelle cheese, Kashar cheese, and Karg1 tulum cheese and found to be in parallel with the amounts found in Karın Kaymağ cheese. According to the analyses, it is found that the duration of maturation has a significant effect on titratable acidity, dry matter and salt values of Kars Gravyer cheese $(P<0.001)$.

The average amounts of fat measured in the cheese samples were determined on day 0 as $26.00 \pm 0.00 \%$, on the 10th day as $28.00 \pm 0.51 \%$, on the 25 th day as $29.50 \pm 0.70 \%$, on the 45th day as $32.00 \pm 0.71 \%$, on the 60th day $33.57 \pm 0.72 \%$ and on the 90 th day $35.50 \pm 0.71 \%$. The values obtained at the end of maturation were found to be lower than the study of Karagöl (2017) on Karın Kaymağ 1 cheese (32.75-48.25\%) and found to be higher than the value in the study of Badem \& Uçar (2016) on Kashar cheese (23.67-25.33\%) and the values in the study of Sar1 et al. (2018) on Mengen cheese (19.05\%). The ANOVA test results to determine the differences in maturation times of fat values of the cheese samples are given in Table 1. As seen 
in Table 1, fat values from certain periods are found to be significantly different from each other $(P<0.001)$. This difference, the fact that the maturation period lengthens out depending on the increase in the dry matter of cheese can be explained by the increase in amounts of fat. The use of different races of animals, the contents of milk and production methods can be effective on different fat ratios. It is also partly due to the fact that some of the studies are only market researches and there are cheeses with very large fat content on the market .

The fat amounts in the dry matter of the cheese samples were calculated and the results were given in Table 1 . The values obtained at the end of maturation were found to be similar to the values determined by Gölge (2009) in Kelle cheese (43.59-46.66\%) and lower than the value determined by Karagöl (2017) in Karın Kaymağ 1 cheese (57.35-59.70\%) The reason for these differences can result from using the different types of milk and different processing types.

Average salt amounts in dry matter determined during maturation of the cheese samples were found to be $0.75 \pm 0.04 \%$ on day $0,1.94 \pm 0.07 \%$ on day $10,2.10 \pm 0.11 \%$ on day 25 , $3.15 \pm 0.40 \%$ on day $45,4.01 \pm 0.41 \%$ on day 60 and $5.21 \pm 0.33$ on day 90.

The salt amounts in average dry matter determined in the cheese samples were found to higher than the values found in Badem \& Uçar (2016) of kashar cheese (2.21-2.45\%) and in the study of Karagöl (2017) which studied Karın Kaymağı cheese (\% 4.06 - 4.12) and were found to be low in the study of Gölge (2009) which studies Kelle cheese (8.93-12.70\%) and in the study of Sert (2011) which studied Kashar cheese produced from raw milk (5.67-6.11\%). The salt amounts in the dry matter of the cheese samples were found to be significantly different as seen in Table $1(P<0.001)$. The difference emerged in the salt ratios in the dry matter of protein samples can be explained by having different acidity values and absorbing different amount of salt in parallel with using different milk combinations during production.

The protein values of the cheese samples are presented in Table 1. While the amount of protein increased until the 60th day, it decreased on the 90th day. The available values were found to be higher than the value of Karg1 Tulum cheese (21.37\%) found in the study of Dinkçi et al. (2012), the value of Karın Kaymağ 1 cheese (21.27-27.79\%) in the study of Karagöl (2017) and the value of Afyon tulum cheese (22.48\%) in the study of Kara \& Akkaya (2015) and the values of Kashar cheese (25.79-32.41\%) in the study of Sert (2011) was found to be in between the values determined in Kars Gravyer cheese. A decrease occurred in the protein amount towards the end of the maturation. This decrease in protein amounts can be explained by partial degradation of proteins followed by turning into water-soluble nitrogenous substances. After statistical analyses, there was a significant difference in the protein amounts of cheese during all maturation processes $(P<0.001)$.

Yaygın \& Dabiri (1989) reported a decrease in the protein amounts of Kashar cheese during the maturation process.

The total nitrogen values of the Kars Gravyer cheese samples are given in Table 1. When the total nitrogen ratios of the cheese samples investigated, the total nitrogen values of samples varied between $4.81-5.75 \%$ and the differences between samples were found to be significant $(P<0.001)$.

The lipolysis triglycerides in cheese are shaped with dissociation of ester bonds between glycerol and fatty acids with lipolytic enzymes. The lipolytic activity, which has an important function in the development of aroma, is evaluated by determining the free acid value (ADV, Acid Degree Value). The ADV value of Kars Gravyer cheese increased (from 0.78 to 2.98), and after the statistical analysis, it was determined that there was a difference between the lipolysis (ADV) ratios of cheese during all periods of maturation $(P<0.001)$. Lipolysis values in Kars Gravyer cheese were higher than the ADV values (0.69-1.13) of Mengen cheese determined by Sar1 et al. (2018) while the values (0.51-2.68 ADV) of Karın Kaymağı cheese determined by Karagöl (2017) were found to be between the values determined in Kars Gravyer cheese. The main reason for an increase in lipolysis values is the breakage of ester bonds between glycerol and fatty acids with lipolytic enzymes. In the differences emerging in the cheese samples, the production of the cheese samples from different types of milk combinations, the biochemical changes occurring during maturation, and samples having different fat contents play an important role.

\subsection{Microbiological properties}

One of the most important factors which affect the quality of cheese is microbiological flora. The microflora of cheeses is results from the microorganisms in the milk used in production and the contaminations during and after the production. The number and type of microorganisms that make up the microflora varies due to the chemical and physical properties of the cheese as well as the interaction between the bacteria during maturation. For this reason, application of strict quantitative microbiological standards is avoided in microbiological quality control of cheese (Ardıç, 2003).

The microbial analysis results of Kars Gravyer cheese are given in Table 2. The highest total number of aerobic mesophilic (TAMB) microorganisms during maturation was on the 45 th day of maturity $(9.40 \pm 0.03)$, and the number of microorganisms decreased from the 60th day. After statistical analysis, it was determined that the total number of aerobic mesophilic microorganisms in the cheese during the whole maturation period was significantly different $(P<0.001)$. The total number of aerobic mesophilic microorganisms was higher than the values which were $2.3 \times 10^{7} \mathrm{kob} \mathrm{g}^{-1}$ determined Kamber et al. (2008) and was similar to the values determined as 5.90-8.90 $\operatorname{log~CFU~g~}^{-1}$ in Kars Gravyer cheese by Topuk \& Sezer (2015). In addition, the values determined by Badem \& Uçar (2016) in kashar cheese as 5.17-5.75 $\log \mathrm{CFU} \mathrm{g}^{-1}$ the values determined by Dinkçi et al. (2012) in Karg1 Tulum cheese as 5.17-5.75 log kob g-1 are higher than the values found in the Kars Gravyer cheese samples and was similar to the values (7.49-8.45) of Mengen cheese determined by Sar1 et al. (2018).

Gravyer cheese is a cheese type whose maturation takes a long time. The change in maturation period of the analyzed cheeses will, of course, change the microbiological and chemical 
composition (Fox et al., 2004a; Fox et al., 2004b; Gunasekaran \& Ak, 2003).

The highest number of lactobacilli microorganisms during the maturation period was on the 25 th day of maturation $(8.54 \pm 0.57)$ and the number of microorganisms started decreasing on the 45th day. As a result of statistical analysis, the difference between the lactobacilli microorganism counts of cheese in all periods of maturation period was found to be insignificant $(P>0.05)$. Kamber et al. (2008) determined the number of lactobacillus as $5.1 \times 10^{5} \mathrm{CFU} \mathrm{g}^{-1}$ in Kars Gravyer cheese, Topuk \& Sezer (2015) determined as 3.90-8.30 log CFU g-1. Badem \& Uçar (2016), determined the number of lactobacillus in Kashar cheese as 5.49-6.98 $\log \mathrm{CFU} \mathrm{g}^{-1}$. The number of lactobacillus determined in the cheese samples is higher than the values of the researchers.

The highest number of lactococcus was found on the 25th day $(8.77 \pm 0.08)$ and the lowest on the 60th day $(6.61 \pm 0.40)$ in the cheese samples. As a result of the statistical analysis, it was determined that there was a difference between the lactococcal bacterial counts of cheese in all periods of maturation $(P<0.001)$. Kamber et al. (2008) determined the number of lactococcus in Kars Gravyer cheese as $8.5 \times 10^{6} \mathrm{CFU} \mathrm{g}^{-1}$. The values found in the cheese samples were higher than the values determined by Kamber et al. (2008). The total number of bacteria and the number of Lactic acid bacteria in the cheese samples were found to be high. Lactic acid bacteria and propionic acid bacteria dominate and increase in number during the prolonged maturation period in Gravyer cheese.

According to Poullet et al. (1991) and Tornadijo et al. (1995) Lactic acid bacteria (LAB) activity was higher at the beginning of ripening because of abundance of food, high water content and low acid concentration. The water amount decreases as a result of the microbial activity, salt and acidity concentration increases and also LAB number decreases towards the end of the ripening period.

No coliform bacteria have been detected in Gravyer cheese samples.

Some moulds and some bacteria can develop on the surface of the Gravyer and contribute positively to the cheese flavor. They are also effective on lipolysis and proteolysis in cheese (Robinson, 2002; Walstra et al., 1999). Moulds that develops on the surface in the first three weeks of cheese maturation neutralizes acidity on the surface by increasing in number. Yeast-moulds are microorganisms that play a role in the deterioration of foodstuffs. The number of yeast-mould was found to be the least $\log \mathrm{CFU} / \mathrm{g}$, the most as $5.80 \pm 0.03 \log \mathrm{CFU}$ $\mathrm{g}^{-1}$ and average as $1.34 \pm 2.41 \log \mathrm{CFU} \mathrm{g^{-1 }}$, respectively, in the Kars Gravyer cheese samples at maturation stage (Table 2). The findings obtained were found to be lower than the average value of $2.10 \pm 1.39 \log \mathrm{CFU} \mathrm{g}^{-1}(<1.0-4.60)$ obtained from 40 pieces of the Kars Gravyer cheese samples obtained from different sales points in Kars in Topuk \& Sezer (2015)'s study, and the average value of $3.9 \times 10^{4} \mathrm{CFU} \mathrm{g}^{-1}$ obtained from Kars Gravyer cheese by Kamber et al. (2008) again in Mengen cheese, Sar1 et al. (2018) determined that the number of yeast moulds was $4.97 \pm 1.15 \mathrm{log}$ CFU g ${ }^{-1}$ on the average and Badem \& Uçar (2016), determined the number of yeast mould as 3.66-4.88 $\log \mathrm{CFU} \mathrm{g}^{-1}$ in the kashar cheese. The values obtained from Mengen and Kashar cheeses are higher than those of Kars Gravyer cheese. The high level of findings in the research is probably due to the fact that the specimens examined are kept on open shelves under different atmospheric conditions in sale points and produced by using different production techniques. Gravyer Cheese Standard does not contain much yeast and mould in 100 grams per gram of cheese (Turkish Standards Institution, 1989). The average number of yeast moulds obtained after the end of the study is within the range specified in the cheese standard.

The number of psychrophile microorganisms were found to be 3.42-7.82 log CFU g g $^{-1}$ in Kars Gravyer cheese and were found $6.73 \pm 2.02 \log \mathrm{CFU} \mathrm{g} \mathrm{g}^{-1}$ on average. The results of the ANOVA test to determine the differences in maturation times of the cheese samples in terms of the number of psychrophilic microorganisms are given in Table 2. As seen in the chart, the difference between the number of psychrophile microorganisms belonging to the period was not statistically significant $(P>0.05)$. The average number of psychrophile bacteria was found to be $3.92 \log$ CFU g $^{-1}$ (3.07-5.83) in Afyon Tulum cheese produced in Afyonkarahisar province and $4.29 \pm 1.55 \log _{10} \mathrm{CFU} \mathrm{g}^{-1}$ by Morul \& İşleyici (2012) in Divle Tulum cheese. The value determined in the Kars Gravyer cheese samples was found higher than the values determined by researchers in different cheese types.

\section{Conclusion}

The industrial production of Gravyer cheese, which is one of the European style cheese produced in Turkey is rather low. Production is carried out by conventional methods mostly in dairy farms. In this study aiming to elucidate the total quality the dry matter, fat, salt, fat in dry matter, salt in dry matter, lipolysis and titratable acidity (\% l.a) values of cheese samples were found to increase whereas and the protein and total nitrogen values decreased on the 90th day during the maturation period of the cheese, which is produced by means of the traditional method in dairy farms and known as Kars Gravyer Cheese; The number of acid bacteria was high due to the fact that the lactic acid bacteria were dominant and increased in number during the prolonged maturation period in Kars Gravyer cheese. Coliform bacteria were not detected in the cheese samples. The average number of yeast and molds obtained after the end of the study is within the range specified in the cheese standard. According to the Gravyer cheese standard, it is stated that the ratio of dry matter should be $62 \%$, the dry matter salt ratio should be $3-10 \%$, and the dry matter should be in the range of $30-45 \%$. While the dry matter of the cheese samples was determined as $57.92 \pm 0.15 \%$ on day 0 and $77.69 \pm 0.09 \%$ on the 90 th day, the fat in dry matter were determined as $43.95 \pm 0.06$ on day 0 and $47.85 \pm 0.11$ on the 90th day, the salt ratio in dry matter was determined $0.75 \pm 0.04$ on day 0 and $5.21 \pm 0.33$ on the 90th day and it was found to be within the standard range.

The total number of bacteria and the number of lactic acid bacteria were found to be high in the samples. Lactic acid bacteria and propionic acid bacteria dominate and increase in number during maturation due to the long-term maturation period in the Kars Gravyer cheese. 
Coliform bacteria were not detected in the Kars Gravyer cheese samples produced in dairy farms. This may be indicative of the fact that these enterprises act consciously to comply with hygiene rules at every stages of production from the purchasing of milk.

The Kars Gravyer cheese, which has economic value for the people of the region produced in and around Kars province, has nationwide brand awareness. Most of the Gravyer cheeses manufactured in Turkey is produced by conventional methods using raw milk. In order to increase consumer demand and to participate in the market and to provide a competitive environment, a standard quality should definitely be achieved. Therefore, healthy food production can be achieved by observing hygiene rules at every stage of production in dairy farms and industrial enterprises engaged in Gravyer manufacturing. In processes to produce Gravyer cheese, the application of the HACCP program should be made compulsory. This major shortcoming should be addressed, certain regulations should be brought into production in dairy farms and production should be moved from small family farms to factories. In this case, however, it can be stated that packaging products with quality standard labeling can be produced and continuity in the market is possible. The production of Kars Gravyer cheese, which is famous for its unique taste and aroma, and which is an important demand in big cities such as Istanbul and Ankara must be in modern and hygienic conditions and it is necessary to have sensory, chemical and microbiological standards in production of Kars Gravyer cheese. We can state that this study can contribute to the production-based studies related to Kars Gravyer cheese and studies to be done for geographical indication.

\section{Acknowledgements}

Authors wish to thank the Research Fund of Kafkas University (No. 2017-FM-02) for the financial support.

\section{References}

Adam, R. C. (1956). Türkiye süt ve mamullerinin bileşimi (Ziraat Fakültesi Yayınlar1, no. 92). Ankara: Ankara Üniversitesi.

Ardiç, M. (2003). Effects of pasteurization and different scalding temperatures on the quality of Urfa cheese (PhD Thesis). Selçuk University, Konya, Turkey.

Badem, A., \& Uçar, G. (2016). A study on chemical and microbiological properties of Kashar cheese produced without using starter culture. Eurasian Journal of Veterinary Sciences, 32(3), 188-192. http://dx.doi. org/10.15312/EurasianJVetSci.2016318399

Cakmakc1, S. (2008, May 21-23). Peynirde olgunlaşma, In 10. Gıda Kongresi. Erzurum: Atatürk Üniversitesi Ziraat Fakültesi Gıda Mühendisliği bölümü, Türkiye.

Cetinkaya, A. (2005). Yöresel peynirlerimiz (1st ed.). Trabzon: Academic Book Production.

Dinkçi, N., Ünal, G., Akalın, A. S., Varol, S., \& Gönç, S. (2012). Chemical and microbiological properties of Karg1 Tulum Cheese. Journal of Agriculture Faculty of Ege University, 49(3), 287-292. http://egeweb. ege.edu.tr/zfdergi/edergiziraat/2012_cilt49/s3/11.pdf

Düzey II Bölgeleri Kalkınma Programı. (2007). Pazarlama araştırmaları, süt ve süt ürünleri - TRA2 (RD-AKKM.419.TR). Ankara: Ulusal Tez Merkezi.
Fox, P. F. (1989). Proteolysis during cheese manufacture and ripening. Journal of Dairy Science, 72(6), 1379-1400. http://dx.doi.org/10.3168/ jds.S0022-0302(89)79246-8

Fox, P. F., \& Mcsweeney, P. L. H. (1996). Proteolysis in cheese during ripening. Food Reviews International, 12(4), 457-509. http://dx.doi. org/10.1080/87559129609541091

Fox, P. F., McSweeney, P. L. H., Cogan, T. M., \& Guinee, T. P. (2004a). Cheese chemistry: physics and microbiology (3rd ed., vol. 2, Major Cheese Groups). London: Elsevier Academic Pres.

Fox, P. F., McSweeney, P. L. H., Cogan, T. M., \& Guinee, T. P. (2004b). Cheese chemistry: physics and microbiology (3rd ed., vol. 1, General Aspects). London: Elsevier Academic Pres.

Fox, P. F., O’Connor, T. P., Mcsweeney, P. L. H., Guinee, T. P., \& O’Brien, N. M. (1996). Cheese: physical, biochemical, and nutritional aspects. Advances in Food and Nutrition Research, 39, 163-328. http://dx.doi. org/10.1016/S1043-4526(08)60075-3. PMid:8794552.

Gölge, Ö. (2009). Influence of the starter culture on the characteristıcs of kelle cheese (PhD Thesis). Çukurova University, Adana, Turkey.

Grappin, R., Lefier, D., Dasen, A., \& Pochet, S. (1993). Characterizing ripening of Gruyere de comte: influence of time $\times$ temperature and salting conditions on eye and slit formation. International Dairy Journal, 3(4-6), 313-328. http://dx.doi.org/10.1016/0958-6946(93)90020-Z.

Gunasekaran, S., \& Ak, M. M. (2003). Cheese rheology and texture. Boca Raton: CRC Pres Taylor \& Francis Group.

Hagen, M., \& Nervus, A. (1999). Production of ice cream containing probiotic bacteria. Milchwissenschaft. Milk Science International, 54, 265-268.

Halkman, A.K. (2005). Merck Gıda mikrobiyolojisi uygulamaları (1st ed.). Ankara: Başak Matbaacılık Ltd Şti.

Huc, D., Roland, N., Grenier, D., Challois, S., Michon, C., \& Mariette, F. (2014). Influence of salt content on eye growth in semi-hard cheeses studied using magnetic resonance imaging and $\mathrm{CO}_{2}$ production measurements. International Dairy Journal, 35(2), 157-165. http:// dx.doi.org/10.1016/j.idairyj.2013.11.010

International Dairy Federation - IDF. (1982). Determination of the total content: cheese and processed cheese (IDF Standard 4A). Brussels: IDF.

International Dairy Federation - IDF. (1991). Milk and milk products: routine methods for determination of free fatty acids in milk (IDF Standard Method 50b). Brussels: IDF.

International Dairy Federation - IDF. (1993). Milk Determination of nitrogen content (IDF Standard Method 20). Brussels: IDF.

Kamber, U., Elmalı, M., \& Yaman, H. (2008). Microbiological and chemical properties of gravier cheeses. Atatürk University Journal of Veterinary Sciences, 3(1), 1-7. http://dergipark.gov.tr/ataunivbd/ issue $/ 2897 / 40225$

Kara, R., \& Akkaya, L. (2015). Determination of microbiological, physico-chemical properties and distribution of lactic acid bacteria of Afyon tulum cheese. Afyon Kocatepe University Journal of Science and Engineering, 15(1), 1-6. http://dx.doi.org/10.5578/fmbd.8717.

Karagöl, M. A. (2017). Investıgation of the changes that occur with aging of the Karın Kaymağ cheese produced from cow milk and sheep milk (MSc. Thesis). Ordu University, Ordu, Turkey.

Kars Sanayi ve Ticaret Odası Müdürlüğü - KARSTSO. (2015). Kars 2015 yil süt ve ürünleri kapasite raporu. Kars: KARSTSO.

Morul, F., \& İşleyici, Ö. (2012). Chemical and microbiological properties of Divle tulum cheese. Van Veterinary Journal, 23(2), 71-76. http:// vfdergi.yyu.edu.tr/archive/2012/23-2/2012_23_(2)_71-76.pdf

Poullet, B., Huertas, M., Sa'nchez, A., Ca'ceres, P., \& Larriba, G. (1991). Microbial study of Casar de a'ceres cheese throughout ripening. The 
Journal of Dairy Research, 58(1), 231-238. http://dx.doi.org/10.1017/ S0022029900029770

Robinson, R. K. (2002). Dairy microbiology handbook: the mikrobiology of milk and milk products (3rd ed.). New York: John Wiley and Sons Inc. http://dx.doi.org/10.1002/0471723959

Sarı, K., Yaman, H., Coşkun, H., \& Akoğlu, A. S. (2018). Mıcrobıal qualıty, volatile compounds profile, textural and some chemical properties of traditional Mengen cheese. The Journal of Food, 43(2), 185-196.

Sert, D. (2011). Determination of some alterations occurred during the ripening period of tulum cheese, traditionally produced from different milk origins (PhD Thesis). Selçuk Üniversity, Konya, Turkey.

Steele, J. L., \& Ünlü, G. (1992). Impact of lactic acid bacteria on cheese flavor development. Food Technology, 46, 128-135.

Topuk, Ş., \& Sezer, Ç. (2015). Some qualıty characterıstıcs of Kars Gravyer cheese. The Journal of Food, 40(2), 69-75.

Tornadijo, M. E., Fresno, J. M., Bernardo, A., Sarmiento, R. M., \& Carballo, J. (1995). Microbiological changes throughout the manufacturing and ripening of Spanish goat's raw milk cheese (Armada variety). Le Lait, 75(6), 551-570. http://dx.doi.org/10.1051/lait:1995643

Tuik. (2016). Sanayi ürünleri yıllık üretim ve satış istatistikleri. Retrieved from www.tuik.gov.tr

Turkish Standards Institution - TSE. (1978). Van gulik methods - official methods of analysis. Ankara, Turkey: Turkish Standards Institution.

Turkish Standards Institution - TSE. (1989). Official methods of analysis (TSE - TS2174). Ankara, Turkey: Turkish Standards Institution.
Turkish Standards Institution - TSE. (1996). Official methods of analysis (TSE - TS 7569 ISO 4832). Ankara, Turkey: Turkish Standards Institution.

Turkish Standards Institution - TSE. (2004). Official methods of analysis (TSE - TS ISO 7889). Ankara, Turkey: Turkish Standards Institution.

Turkish Standards Institution - TSE. (2006). Official methods of analysis (TSE - TS 591). Ankara, Turkey: Turkish Standards Institution.

Uçüncü, M. (2004). A'dan Z’ye peynir teknolojisi. İzmir: Ege Üniversitesi, Mühendislik Fakültesi, Gıda Müh, Bölümü Cilt 1.

Ulutaş, Z., Çağlar, A., \& Kurt, A. (1993). Kars Gravyer peynirinin yapılışı. duyusal. fiziksel ve kimyasal özellikleri üzerinde bir araștırma. Gida, 18, 197-202. http://www.gidadernegi.org/TR/Genel/BelgeGoster.aspx

Walstra, P., Geurts, T. J., Noomen, A., Jellema, A., \& Boekel, M. A. J. S. (1999). Dairy technology: principles of milk properties and processes. New York: Marcel Dekker Inc.

Yaygın, H., \& Dabiri, K. (1989). İnek, koyun, keçi sütleriyle yapılan ve farklı sıcaklıklarda olgunlaştırılan kaşar peynirlerinin özellikleri üzerinde araștırmalar. Ege Üniversitesi Ziraat Fakültesi Dergisi, 26(1), 333-346.

Yöney, Z. (1970). Süt ve Mamülleri (no. 421). Ankara: Ankara Üniversitesi Ziraat Fakültesi Yayınları.

Zerfiridis, G. K., Vafopoulou-Mastrogiannaki, A., \& LitopoulouTzanetaki, E. (1984). Changes during ripening of commercial gruyere cheese. International Dairy Journal, 67(7), 1397-1405. http://dx.doi. org/10.3168/jds.S0022-0302(84)81454-X. 